\title{
Effect of conjugated linoleic acid (CLA) on the performance and serum variables of broiler chickens intoxicated with aflatoxin $B_{1}$
}

\author{
M. Denli ${ }^{1 \#}$, F. Okan ${ }^{1}$ and F. Doran ${ }^{2}$ \\ ${ }^{1}$ Çukurova University, Agricultural Faculty, Department of Animal Science, 01330 Adana, Turkey \\ ${ }^{2}$ Çukurova University, Medical Faculty, Department of Pathology, 01330 Adana, Turkey
}

\begin{abstract}
The purpose of this study was to investigate the protective effect of dietary conjugated linoleic acid (CLA) on the prevention of aflatoxin $\mathrm{B}_{1}\left(\mathrm{AFB}_{1}\right)$ toxicity in the broiler chicken. A total of 99 Ross 308 male broiler chicks was assigned to nine treatments for $42 \mathrm{~d}$. The experiment had a $3 \mathrm{X} 3$ factorial arrangement of treatments involving 0,2 and $4 \mathrm{~g} \mathrm{CLA} / \mathrm{kg}$ feed, and 0,200 and $300 \mathrm{ng} \mathrm{AFB}_{1} / \mathrm{kg}$ feed. The parameters evaluated, were feed intake, body weight gain, feed efficiency, mortality, relative weights of liver and serum levels of total protein, total albumin, uric acid, alkaline phosphatase (ALP), aspartate aminotransferase (AST) and alanine aminotransferase (ALT). Aflatoxin $\mathrm{B}_{1}$ in the diet negatively affected body weight gain and feed efficiency parameters when the birds were 21 and 42 days of age. Altered serum biochemical or hematologic measurements induced by $\mathrm{AFB}_{1}$ treatments included increased serum activities of ALP, AST and ALT, decreased serum concentrations of albumin, total protein and uric acid. Liver weight was increased in birds given $\mathrm{AFB}_{1}$ contaminated diet. The results indicated that CLA alone had insignificant effects on all parameters tested. However, birds receiving $\mathrm{CLA}+\mathrm{AFB}_{1}$ had a significantly higher body weight gain on day 42 than groups receiving $\mathrm{AFB}_{1}$ alone. In addition, co-treatment with $\mathrm{AFB}_{1}$ and $\mathrm{CLA}$ resulted in a significant improvement in feed efficiency and decreased relative weight of liver as compared with the $\mathrm{AFB}_{1}$ groups. These results suggest that CLA provided protection against negative effects on liver damage induced by $\mathrm{AFB}_{1}$ in broiler chickens.
\end{abstract}

Keywords: Aflatoxin $\mathrm{B}_{1}$, conjugated linoleic acid, performance, biochemical parameters, broilers

\#Corresponding author. E-mail: mdenli@mail.cu.edu.tr

\section{Introduction}

The aflatoxins are a group of secondary metabolites produced by certain strains of fungi, e.g. Aspergillus flavus and Aspergillus parasiticus species. Agricultural commodities such as maize, peanut, cottonseed, wheat and other animal feedstuffs are frequently contaminated with aflatoxins. There are four major naturally occurring aflatoxins. The most hepatotoxic one is aflatoxin $\mathrm{B}_{1}\left(\mathrm{AFB}_{1}\right)$. Other structurally similar compounds are aflatoxins $B_{2}, G_{1}$ and $G_{2}$. All four have been detected as contaminants of crops before harvest, between harvesting and storing and after processing and manufacturing. In view of their potential hazards to human and animal health authorities in nearly all the countries of the world have imposed strict regulatory upper limits for aflatoxin concentrations in foods and feeds, usually at very low concentrations.

The main biological effects of aflatoxins are carcinogenicity, immunosuppression, mutagenity and teratogenity in a wide range of animals (Busby \& Wogan, 1984). Avoidance of contaminated feed is rarely possible and feeds that contain relatively low concentrations of $\mathrm{AFB}_{1}$ may still have deleterious effects on sensitive species, such as poultry (Doerr et al., 1983; Giambrone et al., 1985;).

Aflatoxins are metabolised by the liver and metabolic alterations are produced with a decrease in the synthesis of proteins, lipids, nucleic acids and vitamins (Ramos et al., 1997). In poultry even small amounts of $\mathrm{AFB}_{1}$ can cause a reduction in growth performance, hatchability and an increased susceptibility to bacterial and viral diseases and severe hepatotoxicosis (Kubena et al., 1995; Verma et al., 2003). These alterations produce changes in the biochemical parameters, mainly in enzyme levels as have been well documented in broiler chickens (Rosa et al., 2001; Perozo et al., 2003), turkeys (Giambrone et al., 1985; Klein et al., 2002), quails (Rao et al., 1995; Oliveira et al., 2002) and ducks (Cheng et al., 2000). In serum, several clinical indicators are adversely affected by contaminated diet. They include serum urea, albumin, total protein, aspartate aminotransferase (AST, EC: 2.6.1.1), alanine aminotransferase (ALT, EC: 2.6.1.2) and gamma-glutamiltransferase (GGT, EC: 3.2.3.1) (Abdel-Wahhab et al., 2002). 
A variety of physical, chemical and biological approaches employed to counteract the aflatoxin problem has been reported in the literature on mycotoxins (Doyle et al., 1982; Amra et al., 1997). Dietary additions of zeolite and bentonite (Kececi et al., 1998), hydrated sodium calcium aluminosilicate and activated charcoal (HSCAS) (Edrington et al., 1996; Ramos \& Hernandez, 1997), clinoptilolite (Oguz et al. 2000), dry yeast Saccharomyces cerevisiae (Celik et al., 2001) and charcoal (Dalvi \& Ademoyero, 1984; Dalvi \& McGowan, 1984) have been used.

Conjugated linoleic acid (CLA) is a group of positional and geometrical isomers of linoleic acid C18:2 cis-9, cis-12. The CLA cis-9, trans-11 involves the exchange of the cis or trans configuration double bond in linoleic acid located positions 9 and 11 or 10 and 12. Conjugated linoleic acid has been shown to have anticarcinogenic effects in various cancer models, such as chemically induced skin, stomach and colorectal cancer (Aro et al., 2000) and mammary tumorigenesis. Rats and mice that were fed CLA showed a lower tumour incidence and less tumour progression, and also reduced metastasis (Yurawecz et al., 1999). In experiments with human breast cancer cell lines, CLA containing culture media decreased cell growth (Durgam \& Fernandes, 1997). A recent study using CLA enriched butterfat, which contained the natural isomer distribution also showed anticarcinogenic effects (Aro et al., 2000). Other beneficial effects of CLA include reduction in body fat, immuno-modulation and antioxidant properties (Cook et al., 1993; Cantwell et al., 1999).

Due to these properties CLA was selected for use in this experiment. The purpose of this experiment was to investigate the potential of CLA to reduce the toxic effects of $\mathrm{AFB}_{1}$ with respect to growth performance, immune responses and other parameters in growing chickens.

\section{Materials and Methods}

A total of 99 1-day old male Ross 308 broiler chickens with a mean weight $42.8 \mathrm{~g}$ was weighed, individually caged, numbered and divided into nine treatment groups of 11 birds per group. The nine treatments, arranged according to a $3 \times 3$ factorial design, consisted of three levels of $\mathrm{AFB}_{1}$, viz. 0, 200 and $300 \mathrm{ng} / \mathrm{kg}$ feed and three levels of CLA, viz. 0, 2 and $4 \mathrm{~g} / \mathrm{kg}$ feed. Pure crystalline AFB $_{1}$ was obtained from Sigma-Makor Chemical Corp., Jerusalem, Israel. The $\mathrm{AFB}_{1}$ was weighed and dissolved under a hood in warm chloroform at $1 \mathrm{mg} / 10 \mathrm{~mL}$. The $\mathrm{AFB}_{1}$ solution in chloroform was then sprayed on a thin layer $(<1 \mathrm{~cm})$ of the basal diet. The treated feed was left overnight at room temperature for the solvent to evaporate and was then mixed into the basal diet to provide the desired levels of $\mathrm{AFB}_{1} / \mathrm{kg}$ of diet. Conjugated linoleic acid was purchased from the Cognis Corporation, U.S.A. A starter diet was formulated according to the NRC (1994) recommendations to meet the nutrient requirements of broilers during their first 0-21 days, and a grower diet for the following 22 to 42 days. The composition of the basal diets is presented in Table 1. The diets were analysed for aflatoxin content using thin layer chromatography (Howel, 1983).

Each experimental group of the birds received its specific diet ad libitum. Water was provided in continuous flow water troughs. The chicks were reared under a conventional temperature regimen, i.e. starting at $33{ }^{\circ} \mathrm{C}$, and reduced by $3{ }^{\circ} \mathrm{C} /$ week to $21^{\circ} \mathrm{C}$. The relative humidity was maintained at between 60 and $70 \%$. The birds were exposed to continuous lighting. Body weight gain, feed consumption and feed efficiency were calculated weekly. Mortality was recorded and the percentage calculated at the end of the study.

After 42 days all chickens were slaughtered by dislocation of the neck vertebrae and bleeding, and prepared for further analysis. Livers were removed and their weights recorded. Blood samples were collected from all birds from the retroorbital venous plexus at the end of the experimental period for haematological and biochemical study. Within one hour of collection the serum was separated. The serum was then analysed for alkaline phosphatase (ALP, EC: 3.1.3.1), ALT and AST activity, using the SNA-12 clinical method (Anonymous, 1974). Serum albumin concentration was measured using the bromocresol green binding assay (Doumas et al., 1971), total protein in serum using the Biuret reaction (Doumas et al., 1981) and serum uric acid concentration by enzymatic-colorimetry (Barham et al., 1972).

All data were subjected to analysis of variance using the statistical analyses system, SPSS (1993). If appropriate, post-hoc analyses were carried out using the Duncan's test for multiple comparisons. Statements of statistical significance are based on $\mathrm{P}<0.05$. 
Table 1 Composition of basal diets during the experiment $(\mathrm{g} / \mathrm{kg})$

\begin{tabular}{lcc}
\hline & $0-21$ days & $22-42$ days \\
\hline Ingredients & & \\
Maize & 615.0 & 685.5 \\
Soyabean meal & 245.0 & 217.0 \\
Fish meal & 120.0 & 70.0 \\
Dicalcium phosphate & 5.1 & 12.0 \\
DL-methionine & 2.0 & 0.5 \\
Salt & 3.5 & 3.5 \\
Vitamin premix & 3.5 & 3.5 \\
Mineral premix & 2.5 & 3.5 \\
Lysine & 1.2 & 1.0 \\
Choline-Cl & 2.2 & 3.5 \\
Total & 1000 & 1000 \\
Calculate analysis & & \\
Crude protein & 225 & 200 \\
ME (MJ/kg) & 12.88 & 13.38 \\
Calcium & 9.0 & 9.2 \\
Phosphorus & 7.4 & 7.2 \\
L-lysine & 12.0 & 10.0 \\
Methionine+cystine & 9.5 & 7.5 \\
\hline
\end{tabular}

${ }^{a}$ Provided per kg of diet: Vitamin A - $8000 \mathrm{IU}$; vitamin $\mathrm{D}_{3}$. $1200 \mathrm{IU}$; vitamin $\mathrm{E}$ - $10 \mathrm{IU}$; vitamin $\mathrm{K}_{3}$. 2 mg; thiamine - $2 \mathrm{mg}$; riboflavin - $5 \mathrm{mg}$; pyroxidine - $0.2 \mathrm{mg}$; vitamin $\mathrm{B}_{12}$ - $0.03 \mathrm{mg}$; pantothenic acid - $10 \mathrm{mg}$; niacin - $50 \mathrm{mg}$; biotin - $0.1 \mathrm{mg}$; folic acid - $0.5 \mathrm{mg}$

${ }^{\mathrm{b}}$ Provided per kg of diet: Iron - $80 \mathrm{mg}$; zinc - $40 \mathrm{mg}$; manganese - $60 \mathrm{mg}$; iodine - $0.8 \mathrm{mg}$; copper - $8 \mathrm{mg}$; selenium - $0.2 \mathrm{mg}$; cobalt - $0.4 \mathrm{mg}$

\section{Results}

Data presented in Table 2 show the effect of dietary AFB ${ }_{1}$, CLA and their combinations on the growth performance of broilers from 0 to 21 days and 0 to 42 days of the experiment. There were no significant differences between treatment groups at the end of the first 21-day period. However, at the end of the experiment the results showed that the feed containing $\mathrm{AFB}_{1}$ at 200 and $300 \mathrm{ng} / \mathrm{kg}$ feed caused decreases (P $<0.05$ ) in body weight gain and feed efficiency as compared with the control group. The addition of CLA to the $\mathrm{AFB}_{1}$ containing diets partially ameliorated the adverse effects of $\mathrm{AFB}_{1}$ on body weight gain and feed efficiency. No statistically significant differences were found for the feed consumption of the broilers on different treatments. For the duration of the experiment, there was no mortality in any of the treatment groups.

Results of the serum biochemical analysis (Table 3) revealed that treatments with $\mathrm{AFB}_{1}$ alone caused an increase $(\mathrm{P}<0.05)$ in the serum activities of ALT, AST and ALP. Conjugated linoleic acid at $2 \mathrm{or} 4 \mathrm{~g} / \mathrm{kg}$ did not cause significant changes in these serum parameters as compared to the control. Moreover, chicks treated with $\mathrm{AFB}_{1}$ plus CLA generally exhibited improved haematological parameters, but most of them were still higher than in the controls. Data presented in Table 3 show the effect of the dietary treatments on liver weights. The weights of the livers were significantly increased in chicks treated with $\mathrm{AFB}_{1}$. Supplementation of diets containing $\mathrm{AFB}_{1}$ with 2 or $4 \mathrm{~g} / \mathrm{kg}$ CLA decreased the effect of the toxin on the liver weight. However, the addition of the CLA to the control diet had no effect on liver weight.

\section{Discussions}

Aflatoxins are very important to the poultry industry because of their toxicity and frequent occurrence in feedstuffs (Huff et al., 1992). Chronic aflatoxicosis may be diagnosed by determining the serum biochemical and haematological alterations before clinical symptoms become apparent (Kececi et al., 1998). The use of adsorbent materials against mycotoxicosis is a new field that should be completely explored (Ramos \& Hernandez, 1997). In contrast, CLA can have chemo-protective effects in several tissues during multiple stages of carcinogenesis (Belury, 1995) as well as immune enhancing qualities (Cook et al., 1993) and possible antiatherogenic properties (Lee et al., 1994). 
Table 2 Effects of conjugated linoleic acid (CLA) and aflatoxin (AFB $)_{1}$ on body weight gain (BWG), feed consumption (FC) and feed efficiency in male broiler from 0 to 21 and 0 to 42 days of age

\begin{tabular}{|c|c|c|c|c|c|c|}
\hline \multirow[t]{2}{*}{ Treatments } & \multicolumn{2}{|c|}{$\begin{array}{c}\text { Body weight gain } \\
\text { g/bird }\end{array}$} & \multicolumn{2}{|c|}{$\begin{array}{c}\text { Feed consumption } \\
\text { g/bird }\end{array}$} & \multicolumn{2}{|c|}{$\begin{array}{l}\text { Feed efficiency } \\
\text { FC/BWG }\end{array}$} \\
\hline & $0-21$ days & 0-42 days & $0-21$ days & 0-42 days & $0-21$ days & 0-42 days \\
\hline Control & $693^{c}$ & $2265^{\mathrm{bc}}$ & 892 & 3964 & $1.29^{\mathrm{a}}$ & $1.75^{\mathrm{a}}$ \\
\hline $\mathrm{AFB}_{1} 200 \mathrm{ng} / \mathrm{kg}$ & $613^{a b}$ & $2091^{\mathrm{a}}$ & 803 & 3763 & $1.31^{\mathrm{ab}}$ & $1.80^{\mathrm{bc}}$ \\
\hline $\mathrm{AFB}_{1} 300 \mathrm{ng} / \mathrm{kg}$ & $603^{\mathrm{a}}$ & $2025^{a}$ & 796 & 3705 & $1.32^{\mathrm{b}}$ & $1.83^{\mathrm{d}}$ \\
\hline CLA 2 g/kg & $719^{c}$ & $2287^{c}$ & 930 & 4024 & $1.29^{\mathrm{a}}$ & $1.76^{\mathrm{a}}$ \\
\hline CLA 4 g/kg & $676^{\mathrm{abc}}$ & $2271^{\text {bc }}$ & 881 & 3975 & $1.30^{\mathrm{ab}}$ & $1.75^{\mathrm{a}}$ \\
\hline $\begin{array}{l}\text { AFB }_{1} 200 \mathrm{ng} / \mathrm{kg} \\
+ \text { CLA } 2 \mathrm{~g} / \mathrm{kg}\end{array}$ & $665^{\mathrm{abc}}$ & $2213^{b c}$ & 862 & 3960 & $1.30^{\mathrm{ab}}$ & $1.79^{\mathrm{bc}}$ \\
\hline $\begin{array}{l}\text { AFB }_{1} 200 \mathrm{ng} / \mathrm{kg} \\
+ \text { CLA } 4 \mathrm{~g} / \mathrm{kg}\end{array}$ & $656^{\mathrm{abc}}$ & $2245^{b c}$ & 865 & 3996 & $1.32^{\mathrm{b}}$ & $1.78^{\mathrm{b}}$ \\
\hline $\begin{array}{l}\text { AFB }_{1} 300 \mathrm{ng} / \mathrm{kg} \\
+ \text { CLA } 2 \mathrm{~g} / \mathrm{kg}\end{array}$ & $650^{\mathrm{abc}}$ & $2181^{\mathrm{bc}}$ & 850 & 3861 & $1.31^{\mathrm{ab}}$ & $1.77^{\mathrm{ab}}$ \\
\hline $\begin{array}{l}\text { AFB }_{1} 300 \mathrm{ng} / \mathrm{kg} \\
+ \text { CLA } 4 \mathrm{~g} / \mathrm{kg}\end{array}$ & $640^{\mathrm{abc}}$ & $2181^{b c}$ & 844 & 3901 & $1.32^{\mathrm{b}}$ & $1.79^{\mathrm{bc}}$ \\
\hline s.e.m. & 9.32 & 20.06 & 13.2 & 70.2 & 0.006 & 0.01 \\
\hline
\end{tabular}

Pooled s.e.m. - pooled standard error of the mean

${ }^{\mathrm{a}, \mathrm{b}, \mathrm{c}, \mathrm{d}}$ Means within column with different superscripts differ significantly $\mathrm{P}<0.05$

Table 3 Effects of conjugated linoleic acid (CLA) on serum biochemical variables and liver weight in male broiler chickens receiving a diet containing aflatoxin $\left(\mathrm{AFB}_{1}\right)$ for 42 days

\begin{tabular}{|c|c|c|c|c|c|c|c|}
\hline Treatments & $\mathrm{U} / \mathrm{L}$ & $\mathrm{U} / \mathrm{L}$ & $\mathrm{U} / \mathrm{L}$ & $\begin{array}{c}\text { Total } \\
\text { protein } \\
\text { g/dL }\end{array}$ & $\begin{array}{c}\text { Albumin } \\
\text { g/dL }\end{array}$ & $\begin{array}{c}\text { Uric acid } \\
\mathrm{mg} / \mathrm{dL}\end{array}$ & $\begin{array}{l}\text { Liver } \\
\text { weight } \\
\text { g/bird }\end{array}$ \\
\hline Control & $556.9^{\mathrm{a}}$ & $235.8^{\mathrm{a}}$ & $3.8^{\mathrm{a}}$ & $4.16^{\mathrm{c}}$ & 1.44 & $4.36^{\mathrm{b}}$ & $44.8^{\mathrm{a}}$ \\
\hline $\mathrm{AFB}_{1} 200 \mathrm{ng} / \mathrm{kg}$ & $729.7^{\text {cd }}$ & $275.2^{\mathrm{b}}$ & $5.1^{\mathrm{b}}$ & $3.60^{\mathrm{ab}}$ & 1.38 & $3.10^{\mathrm{a}}$ & $51.5^{\mathrm{bc}}$ \\
\hline $\mathrm{AFB}_{1} 300 \mathrm{ng} / \mathrm{kg}$ & $791.2^{\mathrm{C}}$ & $277.9^{\mathrm{b}}$ & $5.8^{\mathrm{b}}$ & $3.30^{\mathrm{a}}$ & 1.36 & $2.94^{\mathrm{a}}$ & $53.4^{\mathrm{c}}$ \\
\hline CLA 2 g/kg & $605.0^{\mathrm{ab}}$ & $233.0^{\mathrm{a}}$ & $3.6^{\mathrm{a}}$ & $4.18^{\mathrm{c}}$ & 1.48 & $4.40^{\mathrm{b}}$ & $45.2^{\mathrm{a}}$ \\
\hline CLA 4 g/kg & $595.6^{\mathrm{ab}}$ & $243.4^{\mathrm{a}}$ & $3.4^{\mathrm{a}}$ & $4.02^{\mathrm{bc}}$ & 1.42 & $4.28^{\mathrm{b}}$ & $44.8^{\mathrm{a}}$ \\
\hline $\begin{array}{l}\mathrm{AFB}_{1} 200 \mathrm{ng} / \mathrm{kg} \\
+ \text { CLA } 2 \mathrm{~g} / \mathrm{kg}\end{array}$ & $671.7^{\mathrm{bc}}$ & $249.1^{\mathrm{a}}$ & $4.0^{\mathrm{ab}}$ & $3.96^{\mathrm{bc}}$ & 1.40 & $4.04^{\mathrm{ab}}$ & $46.1^{\mathrm{a}}$ \\
\hline $\begin{array}{l}\mathrm{AFB}_{1} 200 \mathrm{ng} / \mathrm{kg} \\
+ \text { CLA } 4 \mathrm{~g} / \mathrm{kg}\end{array}$ & $634.5^{\mathrm{abc}}$ & $253.0^{\mathrm{ab}}$ & $4.2^{\mathrm{ab}}$ & $4.06^{\mathrm{c}}$ & 1.42 & $3.80^{\mathrm{ab}}$ & $45.5^{\mathrm{a}}$ \\
\hline $\begin{array}{l}\mathrm{AFB}_{1} 300 \mathrm{ng} / \mathrm{kg} \\
+ \text { CLA } 2 \mathrm{~g} / \mathrm{kg}\end{array}$ & $709.7^{\mathrm{bc}}$ & $261.2^{\mathrm{ab}}$ & $4.9^{\mathrm{b}}$ & $3.94^{\mathrm{bc}}$ & 1.37 & $3.56^{\mathrm{a}}$ & $47.9^{\mathrm{ab}}$ \\
\hline $\begin{array}{l}\mathrm{AFB}_{1} 300 \mathrm{ng} / \mathrm{kg} \\
+ \text { CLA } 4 \mathrm{~g} / \mathrm{kg}\end{array}$ & $628.7^{\mathrm{abc}}$ & $255.6^{\mathrm{ab}}$ & $4.4^{\mathrm{ab}}$ & $3.92^{\mathrm{bc}}$ & 1.41 & $3.62^{\mathrm{ab}}$ & $45.9^{\mathrm{a}}$ \\
\hline s.e.m. & 13.44 & 3.73 & 0.06 & 0.09 & 0.01 & 0.05 & 0.88 \\
\hline
\end{tabular}

ALP - alkaline phosphatase; AST - aspartate aminotransferase; ALT - alanine aminotransferase

Pooled s.e.m. - pooled standard error of the mean

a,b,c,d Means in column with different superscripts differ significantly $\mathrm{P}<0.05$

The South African Journal of Animal Science is available online at http://www.sasas.co.za/Sajas.html 
In this study the results showed that the inclusion of $\mathrm{AFB}_{1}$ at 200 or $300 \mathrm{ng} / \mathrm{kg}$ in the diet significantly reduced growth parameters of broiler chickens such as body weight gain and feed efficiency at the end of the 42-day feeding period. These results agreed with the findings of Rosa et al. (2001) and Bailey et al. (1998). Kubena et al. (1997) also reported that $\mathrm{AFB}_{1}$ has a negative effect on body weight gain and feed efficiency in broiler chickens. Addition of CLA to the $\mathrm{AFB}_{1}$ containing diet significantly alleviated the adverse effects of $\mathrm{AFB}_{1}$ on body weight gain and feed efficiency.

The activities of ALT and AST in serum are sensitive indicators of acute hepatic necrosis, and ALP level is known to be indicative of hepatobiliary disease (Kaplan, 1987). The biochemical changes and alterations in enzyme activities induced a stress on liver function (Abdel-Wahhab et al., 1999). The present study showed that broiler chickens fed an $\mathrm{AFB}_{1}$-contaminated diet had a significant increase in serum ALT, AST and ALP activities compared to those of the controls. This is a well-known effect of aflatoxicosis (Huff et al., 1986). The literature on the effect of adding bentonite to the diet to prevent the adverse effect of aflatoxin is equivocal. Kececi et al. (1998) reported that some serum biochemical changes could be ameliorated by the addition of bentonite at doses of $5 \mathrm{mg} / \mathrm{kg}$ in broiler chicken diets. On the other hand, Santurio et al. (1999) observed that sodium bentonite did not alter the aflatoxin induced changes in the biochemistry of broilers significantly. Although the activities of these enzymes in the present study were reduced in the diets containing $\mathrm{CLA}+\mathrm{AFB}_{1}$, they did not reach the normal values of the control, even when the higher level of CLA, $4 \mathrm{~g} / \mathrm{kg}$, was used. Thus, the properties of CLA in regulating physiological and metabolic responses to immunological challenges remain to be elucidated. Kubena et al. (1990) demonstrated that when hydrated sodium calcium aluminosilicate (HSCAS) was added to broiler chicken diets contaminated with $5 \mathrm{mg}$ aflatoxin, toxicity was reduced. However, it did not effect serum biochemical parameters such as AST activity or serum total protein and albumin concentrations.

Decreases in serum total protein concentration are frequently observed in chickens suffering from aflatoxicosis (Kubena et al., 1997; Kececi et al., 1998). The inhibition of protein synthesis in the liver and the decrease of serum protein concentrations during aflatoxicosis have been reported (Jindal et al., 1994). In the present study, serum total protein and uric acid concentrations were reduced in the treatments containing $\mathrm{AFB}_{1}$, These effects were ameliorated by the addition of $4 \mathrm{~g} \mathrm{CLA} / \mathrm{kg}$ to the diets containing $\mathrm{AFB}_{1}$. The beneficial effect of CLA might be related to the fact that CLA feeding induced a rapid and marked decrease in fat accumulation and an increase in protein deposition (DeLany et al., 1999). Moreover, Cook et al. (1993) observed that $0.5 \%$ dietary CLA modified some aspects of the immune response in chicks.

The liver is considered the principal target organ for aflatoxin toxicity and one classic symptom of aflatoxicosis in broiler is an increase in liver weight (Miazzo et al., 2000). In the present study $\mathrm{AFB}_{1}$ at both the 200 and $300 \mathrm{ng} / \mathrm{kg}$ levels of inclusion caused significant increases in liver weight. The addition of CLA reduced the magnitude of these increases, thus indicating a direct protective effect of CLA on the liver.

The present experiment showed that broiler chicks consuming an aflatoxin contaminated diet experienced a significant decrease in body weight gain with a poorer feed efficiency and increases in activities of serum enzymes. The addition of CLA to the aflatoxin-contaminated diet could reduce the negative effect of aflatoxin on growth performance and liver weight of the broilers.

\section{Conclusions}

Our findings suggest that adding CLA to broiler diets could partially protect the birds against some of the more extreme toxic effects of $\mathrm{AFB}_{1}$. This protective action was evident in body weight gains, feed efficiency and liver weights. These data suggest that CLA could be used to prevent the adverse effects arising from $\mathrm{AFB}_{1}$ ingestion. Further studies are required using different levels of CLA to determine optimal levels of CLA addition to minimise the adverse effects of aflatoxicosis on weight gain and liver functions.

\section{Acknowledgements}

The authors are grateful to Çukurova University Research Fund for their financial support.

\section{References}

Abdel-Wahhab, M.A., Nada, S.A. \& Khalik, F.A., 2002. Physiological and toxicological responses in rats fed aflatoxin-contaminated diet with or without sorbent materials. Anim. Feed Sci. Technol. 97, 209219. 
Amra, H.A., Abdel-Galil, M.M. \& Abdel-Vahhab, M.A., 1997. Biological control of aflatoxins, ochratoxin A and/or fumonisin B production by Thtichoderma harzianum on corn. J. Agr. Sci. Mansoura Univ. 11(22), 3821-3829.

Anonymous, 1974. Technical publication No. UA4-0160-00, Technion Instr. Corp., Terrytown, 1974. pp. 127-129.

Aro, A.S., Mannisto, I., Salminen, M.L., Onaskainen, V., Kataja, V. \& Uustupa, M., 2000. Inverse association between dietary and serum conjugated linoleic acid and risk of breast cancer in postmenopausal women. Nutr. Cancer 38, No. 2, 151-157.

Bailey, R.H., Kubena, L.F., Harvey, R.B., Buckley, S.A. \& Rottinghaus, G.E., 1998. Efficacy of various inorganic sorbents to reduce the toxicity of aflatoxin and T-2 toxin in broiler chicksens. Poult. Sci. 77, 1623-1630.

Barham, D. \& Trinder, P., 1972. An improved colour reagent for the determination of blood glucose by the oxidase system. Analyst 97, 142-145.

Belury, M.A., 1995. Conjugated dienoic linoleate: a polyunsaturated fatty acid with unique chemoprotective properties. Nutr. Rev. 53, 83-89.

Busby, W.F. \& Wogan, G.N., 1984. Aflatoxins. In: Chemical Carcinogens. Ed. Searle, C.E., American Chemical Society, Washington, DC. pp. 945-1136.

Cantwell, H.R., Devery, O’Shea, M. \& Stanton, C., 1999. The effect of conjugated linoleic acid on the antioxidant enzyme defence system in rat hepatocytes. Lipids 34, 833-839.

Cheng, Y.H., Shen, T.F., Pang, V.F. \& Chen, B.J., 2000. Effects of aflatoxin and carotenoids on growth performance and immune response in mule ducklings. Comp. Biochem. Phys. 128, 19-26.

Celik, K., Denli, M., Ertürk, M., Öztürkcan, O. \& Doran, F., 2001. Evaluation of dry yeast Saccharomyces Cerevisiae in the feed to reduce aflatoxin $\mathrm{B}_{1} \mathrm{AFB}_{1}$ residues and toxicity to Japonica Quails Coturnix coturnix Japonica. J. Appl. Anim. Res. 20, 245-250.

Cook, M.E., Miller, C.C., Park, Y. \& Pariza, M.W., 1993. Immune modulation by altered nutrient metabolism: Nutritional control of immune-induced growth depression. Poult. Sci. 72, 1301-1305.

Dalvi, R.R. \& Ademoyero, A.A., 1984. Toxic effects of aflatoxin B1 in chickens given feed contaminated with Aspergillus flavus and reduction of toxicity by activated charcoal and some chemical agents. Avian Dis. 28, 61-69.

Dalvi, R.R. \& McGowan, C., 1984. Experimental induction of cronic aflatoxicosis in chickens by purified aflatoxin B1 and its reversal by activated charcoal, phenobarbital and reduced glutathione. Poult. Sci. 63, 485-491.

DeLany, J.P., Blohm, F., Truett, A.A., Scimeca, J.A. \& West, D.B., 1999. Conjugated linoleic acid rapidly reduces body fat content in mice without affecting energy intake. Am. J. Physiol. 276, 1172-1179.

Doerr, J.A., Huff, W.E., Wabeck, C.J., Chaloupka, G.W., May, J.D. \& Merkley, J.W., 1983. Effects of lowlevel chronic aflatoxicosis in broiler chickens. Poult. Sci. 62, 1971-1977.

Doumas, B.T., Watson, W.A. \& Biggs, H.G., 1971. Albumin standards and the measurement of serum albumin with bromocresol green. Clin. Chim. Acta. 31, 87-96.

Doumas, B.T., Bayse, D.D., Carter, R.J., Peters, J.T. \& Schaffer, R.A., 1981. Candidate reference method for determination of total protein in serum. I. Development and Validation, II. Tests for transferability. Clin. Chem. 27, 1642-1654.

Doyle, M.P., Applebaum, R.S., Brackett, R.E. \& Marth, E.H., 1982. Physical, chemical and biological degradation of mycotoxins in food and agricultural commodities. J. Food Prot. 45, 964-971.

Durgam, R.V. \& Fernandes, G., 1997. The growth inhibitory effect of conjugated linoleic acid on MCF-7 cells is related to estrogen response system. Cancer Lett. 116, 121-130.

Edrington, T.S., Sarr, A.B., Kubena, L.F., Harvey, R.B. \& Phillips, T.D., 1996. Hydrated sodium calcium aluminosilicate HSCAS, acidic HSCAS, and activated charcoal reduce urinary excretion of aflatoxin M1 in turkey poults. Lack of effect by activated charcoal on aflatoxicosis. Toxicol. Lett. 1999, 89, 115-122.

Giambrone, J.J., Diener, U.L., Davis, N.D., Panangala, V.S. \& Hoerr, F.J., 1985. Effects of aflatoxin on young turkeys and broiler chickens. Poult. Sci. 64, 1678-1684. 
Howel, M.V., 1983. Methods for determination of aflatoxins, ochratoxin A and zearalenone in mixed feeds with detection by thin layer chromatography or high performance liquid chromatography. Proc. Int. Symp. Mycotoxins. National Research Centre. Cairo, Egypt, 1983. pp. 293-296.

Huff, W.E., Kubena, L.R., Harvey, R.B. \& Phillips, T.D., 1992. Efficacy of hydrated sodium calcium aluminosilicate to reduce the individual and combined toxicity of aflatoxin and ochratoxin A. Poult. Sci. 71, 64-69.

Jindal, N., Mahipal, S.K. \& Mahajan, N.K., 1994. Toxicity of aflatoxin $B_{1}$ in broiler chickens and its reduction by activated charcoal. Res. Vet. Sci. 56, 37-40.

Kaplan, M.M., 1987. Laboratory tests. In: Diseases of the Liver. Ed. Schiff, L. \& Schiff, E.R., J.B. Lippincott, Philadelphia. p. 219.

Kececi, O., Oguz, H., Kurtoglu, V. \& Demet, Ö., 1998. Effects of polyvinylpolypyrrolidone, synthetic zeolite and bentonite on serum biochemical and haematological characters of broiler chickens during aflatoxicosis. Br. Poult. Sci. 39, 452-458.

Klein, P.J., Vleet, T.R.V., Hall, J.O. \& Coulombe, R.A., 2002. Dietary butylated hydroxytoluene protects against aflatoxicosis in Turkey. Toxicol. Appl. Pharm. 182, 11-19.

Kubena, L.F., Harwey, R.B. \& Huff, W.E., 1990. Efficacy of hydrated sodium calcium aluminosilicate to reduce the toxicity of aflatoxin and T-2 toxin. Poult. Sci. 69, 1078-1086.

Kubena, L.F., Edrington, T.S., Kamps-Holtzapple, C., Harvey, R.B., Elissalde, M.H. \& Rottinghaus, G.F., 1995. Effects of feeding fumonisin $\mathrm{B}_{1}$ present in Fusarium moniliforme culture material and aflatoxin singly and in combination to turkey poults. Poult. Sci. 74, 1295-1303.

Kubena, L.F., Harvey, W.E., Buckley, S.A., Edrington, T.S. \& Rottinghaus, G.E., 1997. Invidual and combined effects of moniliformin present in Fusarium fujikuroi culture material and aflatoxin in broiler chicks. Poult. Sci. 76, 265-270.

Lee, K.N., Kritchevsky, D. \& Pariza, M.W., 1994. Conjugated linoleic acid and atheroscierosis in rabbits. Atheroscierosis 108, 19-25.

Miazzo, R., Rosa, C.A.R., De Queiroz Carvalho, E.C., Magnoli, C., Chiacchiera, S.M., Palacio, G., Saenz, M., Kikot, A., Basaldella, A. \& Dalcero, A. 2000. Efficacy of synthetic zeolite to reduce the toxicity of aflatoxin in broiler chicks. Poult. Sci. 78, 1-6.

NRC, 1994. Nutrient requirements of poultry. (9th ed.). National Academy Press, Washington, D.C., USA.

Oliveira, C.A.F., Rosmaninho, J.F., Butkeraitis, P., Correa, B., Reis, T.A., Guerra, J.L., Albuquerque, S.R. \& Moro, M.E.G., 2002. Effect of low levels of dietary aflatoxin $B_{1}$ on laying Japanese quail. Poult. Sci. 81, 976-980.

Oguz, H. \& Kurtoglu, V., 2000. Effect of clinoptiloite on performance of broiler chickens during experimental aflatoxicosis. Br. Poult. Sci. 41, 512-517.

Ramos, A.J. \& Hernandez, E., 1997. Prevention of aflatoxicosis in farm animals by means of hydrated sodium calcium aluminosilicate addition to feedstuff: a review. Anim. Feed Sci. Technol. 65, 197-206.

Rao, J.R., Sharma, N.N. \& Johri, T.S., 1995. Influence of dietary aflatoxin on Eimeria uzura infection in Japanese quail. Vet. Parasitol. 56, 17-22.

Rosa, C.A.R., Miazzo, R., Magnoli, C., Salvano, M., Chiacchiera, S.M., Ferrero, S., Saenz, M., Carvalho, E.C.Q. \& Dalcero, A., 2001. Evaluation of the efficacy bentonite from the south of Argentina to ameliorate the toxic effects of aflatoxin in broilers. Poult. Sci. 180, 139-144.

SPSS, 1993. SPSSx for Windows. Release, 6.0, Copyright: SPSS Inc., 1989-1993, New York, USA.

Verma, J., Johri, T.S. \& Swain, B.K., 2003. Effect of varying levels of aflatoxin, ochratoxin and their combinations on the performance and egg quality characteristics in laying hens. Asian-Aust. J. Anim. 167, 1015-1019.

Yurawecz, M., Mossoba, M., Kramer, J., Pariza, M. \& Nelson, G., 1999. Advances in conjugated linoleic acid research. Vol. 1. AOCS Press, Champaign, Illinois, USA. 